\title{
Pengaruh Pemberian Ekstrak Biji Melinjo (Gnetum gnemon) Terhadap Kadar Trigliserida pada Tikus dengan Diet Tinggi Lemak
}

Pritasa Muthia Ulfa ${ }^{1}$, Yustini Alioes ${ }^{2}$, Biomechy Oktomalio Putri ${ }^{3}$

\begin{abstract}
Abstrak
Ekstrak biji melinjo (Gnetum gnemon) mengandung berbagai macam stilbenoid yang dikenal sebagai "Resveratrol Melinjo". Resveratrol menurunkan trigliserida dengan mengoksidasi kolesterol LDL dan memodulasi metabolisme lipid. Tujuan penelitian ini adalah untuk mengetahui pengaruh ekstrak biji melinjo terhadap kadar trigliserida tikus diet tinggi lemak. Penelitian ini berjenis eksperimental murni dengan randomized pre-post test randomized control group design yang terdiri dari 5 kelompok (K-, $\mathrm{K}_{+}, \mathrm{P} 1$, P2, dan P3). Kelompok P1 diberikan ekstrak biji melinjo dosis $250 \mathrm{mg} / \mathrm{kg} / \mathrm{hari}$, group P2 $500 \mathrm{mg} / \mathrm{kg} / \mathrm{hari}$, dan group P3 $2000 \mathrm{mg} / \mathrm{kg} / \mathrm{hari}$ dimulai dari hari ke-16 sampai akhir penelitian. Trigliserida diukur dengan metode GPO-PAP. Data dianalisis dengan uji paired t-test. Kadar trigliserida pada kelompok K- menurun dari 89,96 mg/dl menjadi 80,66 mg/dl, kelompok K+ menurun dari 90,36 mg/dl menjadi 84,64 mg/dl, kelompok P1 menurun dari 92,9 mg/dl menjadi 76,3 mg/dl, kelompok P2 menurun dari 90,68 mg/dl menjadi 85,22 mg/dl dan kelompok P3 meningkat dari 73,5 mg/dl menjadi 83,4 mg/dl. Uji paired T-test menunjukkan adanya penurunan trigliserida yang tidak signifikan. Simpulan hasil studi ini adalah ekstrak biji melinjo tidak dapat mengurangi kadar trigliserida pada tikus diet tinggi lemak.
\end{abstract}

Kata kunci: diet tinggi lemak, ekstrak biji melinjo, trigliserida

\begin{abstract}
Melinjo (Gnetum gnemon) seed extract contains many kinds of stilbenoid as known as "Melinjo Resveratrol". Resveratrol decrease triglyceride by oxidating LDL-Cholesterol and modulating lipid metobolism. The objective of this study was to identify the effect of melinjo seed extract in triglceride level of high fat diet rats. This was an experimental study with randomized pre-post test control group design consisted of 5 groups (K-, K+, P1, P2, and P3). Group P1 was given $250 \mathrm{mg} / \mathrm{kg} /$ day, group P2 $500 \mathrm{mg} / \mathrm{kg} /$ day, and group P3 $2000 \mathrm{mg} / \mathrm{kg} /$ day of melinjo seed extract started from the 16th day to the end of the study. Triglyceride was measured by GPO-PAP method. The data were analyzed by paired $\mathrm{t}$-test.Triglyceride level in group $\mathrm{K}$ - group decreased from $89,96 \mathrm{mg} / \mathrm{dl}$ to $80,66 \mathrm{mg} / \mathrm{dl}$, group $\mathrm{K}+$ decreased from 90,36 mg/dl to 84,64 mg/dl, group $P 1$ decreased from 92,9 mg/dl to 76,3 mg/dl, group P2 decreased from 90,68 mg/dl to $85,22 \mathrm{mg} / \mathrm{dl}$, and group P3 increased from $73,5 \mathrm{mg} / \mathrm{dl}$ to $83,4 \mathrm{mg} / \mathrm{dl}$. Based on paired $T$-test analysis showed a nonsignificant decrease in triglyceride. The conclusion of this study showed that melinjo seed extract is unable to reduce triglyceride level of high fat diet rats.
\end{abstract}

Keywords: high fat diet, melinjo seed extract, triglyceride

Affiliasi penulis: 1. Prodi Kedokteran Fakultas Kedokteran Universitas Andalas Padang (FK Unand), 2. Bagian Biokimia Fk Unand, 3. Bagian Histologi Fk Unand
Korespondensi: Pritasa Muthia Ulfa, Email:

pritasamuthia@gmail.com, Telp: +628127567505 


\section{PENDAHULUAN}

Hiperlipidemia merupakan kondisi dimana adanya peningkatan trigliserida dan kolesterol dalam darah. ${ }^{1}$ Keadaan hiperlipidemia pada individu dapat meningkatkan risiko terkena penyakit kardiovaskular pada individu tesebut. Penyakit kardiovaskular adalah penyakit yang disebabkan oleh gangguan jantung dan pembuluh darah seperti penyakit jantung koroner, gagal jantung atau payah jantung, hipertensi, dan stroke. ${ }^{2}$

Penyakit tidak menular menjadi penyebab kematian sebanyak 38 juta. Penyakit kardiovaskular menjadi penyebab hampir 17,5 juta kematian atau sekitar 46,2\% kematian pada tahun 2012. Angka kematian tersebut selalu meningkat dari tahun 2000 sampai sekarang. ${ }^{3}$ Prevalensi penyakit jantung koroner sebesar $0,5 \%$ atau diperkirakan sebesar 883.447 orang, gagal jantung sebesar $0,13 \%$ dan stroke sebesar $7 \%$ berdasarkan wawancara terdiagnosis dokter di Indonesia. Khusus di wilayah Sumatera Barat, prevalensi penyakit jantung koroner sebesar 0,6\%, gagal jantung sebesar $0,13 \%$, dan stroke sebesar $7,4 \%$ yang juga didasarkan atas wawancara terdiagnosis dokter. ${ }^{2}$

Trigliserida termasuk ke dalam jenis lemak netral yang terdiri dari tiga molekul asam lemak yang berkondensasi dengan satu molekul gliserol. Lemak netral adalah unsur utama yang terdapat dalam bahan makanan berasal dari hewan dan sangat sedikit kandungannya dalam bahan makanan berasal dari tumbuhan. 4

Kadar trigliserida di dalam darah dikatakan tinggi apabila melebihi $199 \mathrm{mg} / \mathrm{dl}^{5}$ Semakin tinggi kadar trigliserida di dalam darah suatu individu semakin tinggi pula risiko terkena penyakit kardiovaskular pada individu tersebut. Peningkatan kadar trigliserida dalam darah sebesar 1,0 mmol/L dapat meningkatkan risiko penyakit jantung koroner atau penyakit jantung iskemik sebesar $14 \%$ sehingga kadar trigliserida melebihi $200 \mathrm{mg} / \mathrm{dL}$ perlu diwaspadai dan dikendalikan dengan cepat. ${ }^{6}$

Terapi non-farmakologi seperti diet rendah lemak, aktivitas yang memadai, dan konsumsi buah dan sayuran yang gizinya seimbang dapat mecegah tingginya kadar lipid termasuk trigliserida. ${ }^{7,8}$
Penggunaan bahan alami seperti konsumsi buah, sayuran, atau bahan alaminya menjadi meningkat sehingga eksplorasi terhadap bahan-bahan alam yang dapat berfungsi sebagai penurun dan pencegah naiknya kadar lemak darah semakin giat dilakukan. ${ }^{9}$

Melinjo (Gnetum gnemon L.) merupakan tanaman yang tersebar luas dari wilayah Asia Tenggara sampai Pasifik bagian barat, termasuk di wilayah Indonesia. ${ }^{10}$ Senyawa tersebut disebut sebagai "Resveratrol Melinjo". ${ }^{11}$ Trans-resveratrol juga sangatlah bermanfaat pada manajemen penyakit diabetes dan penyakit kardiovaskular pada manusia. ${ }^{12}$

Berdasarkan permasalahan di atas dan juga didukung beberapa penelitian yang telah dilakukan dan belum adanya penelitian yang dilakukan mengenai pengaruh pemberian ekstrak biji melinjo terhadap penurunan kadar trigliserida, maka penelitian ini penting dilakukan. Tujuan penelitian ini adalah mengetahui kadar trigliserida pada darah tikus wistar yang diberi diet tinggi lemak disertai ekstrak biji melinjo.

\section{METODE}

Jenis penelitian ini adalah eksperimental murni dengan menggunakan rancangan randomized prepost test randomized control group design yang terdiri dari 5 kelompok dengan satu kelompok kontrol negatif, satu kelompok kontrol positif dan tiga kelompok perlakuan.

Pemeliharaan, perlakuan dan pengukuran berat badan hewan coba dilakukan di animal house Fakultas Kedokteran Universitas Andalas. Pengukuran kadar trigliserida serum dilakukan di Laboratorium Biokimia Fakultas Kedokteran Universitas Andalas. Pelaksanaan penelitian dimulai dari September 2017 sampai Maret 2018 mulai dari penyusunan proposal hingga menyelesaikan penelitiannya.

Populasi penelitian ini adalah tikus putih jantan (Rattus novergicus) galur wistar yang berumur 8-12 minggu dengan berat badan berkisar 150-300 gram. Besar sampel minimal yang dibutuhkan dalam penelitian ini ditentukan berdasarkan kriteria World Health Organization (WHO) yaitu sebanyak lima ekor tikus untuk setiap kelompok. ${ }^{13}$ Total sampel untuk lima 
kelompok adalah 25 ekor tikus. Prediksi sampel yang drop out adalah sebesar $10 \%$. Maka sampel ditambah satu ekor untuk setiap kelompok. Total sampel yang dibutuhkan untuk 5 kelompok adalah 30 ekor tikus. Setiap kelompok diberi perlakuan yang berbeda dengan rincian :

Kelompok $1(\mathrm{~K}-)$ : Kelompok yang hanya diberi pakan standar

Kelompok $2(\mathrm{~K}+)$ : Kelompok yang diberi pakan standar dan otak sapi $2 \mathrm{ml} /$ hari dan pakan standar.

Kelompok 3 (P1): Kelompok perlakuan diberi pakan standar dan otak sapi $2 \mathrm{ml} /$ hari selama 29 hari, dan dilanjutkan dengan pemberian ekstrak biji melinjo 250 $\mathrm{mg} / \mathrm{kg} /$ hari dimulai pada hari ke-16.

Kelompok 4 (P2): Kelompok perlakuan diberi pakan standar dan otak sapi $2 \mathrm{ml} /$ hari selama 29 hari dan dilanjutkan dengan pemberian ekstrak biji melinjo 500 $\mathrm{mg} / \mathrm{kg} /$ hari dimulai pada hari ke-16.

Kelompok 5 (P3): Kelompok perlakuan diberi pakan standar dan otak sapi $2 \mathrm{ml} /$ hari selama 29 hari dan dilanjutkan dengan pemberian ekstrak biji melinjo $2000 \mathrm{mg} / \mathrm{kg} / \mathrm{hari}$ dimulai pada hari ke-16.

HASIL

Penelitian telah dilakukan di animal house Fakultas Kedokteran Universitas Andalas dan Laboratorium Biokimia Universitas Andalas selama 37 hari.

Pengukuran trigliserida dilakukan di Laboratorium Biokimia Fakultas Kedokteran Universitas Andalas. Berdasarkan data yang diperoleh didapatkan rerata trigliserida antar kelompok perlakuan. Hasil penelitian disajikan dalam tabel di bawah berikut.

Tabel 1 menunjukkan penurunan trigliserida paling besar terdapat pada kelompok P1 yaitu yang dilakukan pemberian ekstrak biji melinjo dosis 250 $\mathrm{mg} / \mathrm{kgbb} / \mathrm{hari}$ sebesar $17,86 \%$.
Tabel 1. Rerata kadar trigliserida serum sebelum dan setelah ekstrak biji melinjo diberikan

\begin{tabular}{|c|c|c|c|}
\hline Kelompok & $\begin{array}{c}\text { Rerata } \\
\text { Trigliserida } \\
\text { Pre } \\
\text { (mg/dL } \pm S D)\end{array}$ & $\begin{array}{c}\text { Rerata } \\
\text { Trigliserida } \\
\text { Post } \\
\text { (mg/dL } \pm S D)\end{array}$ & $\begin{array}{c}\% \\
\text { Perban- } \\
\text { dingan }\end{array}$ \\
\hline K- & $89,96 \pm 8,09$ & $80,66 \pm 14,05$ & $\begin{array}{c}\text { Penurunan } \\
10,33 \%\end{array}$ \\
\hline $\mathrm{K}_{+}$ & $90,36 \pm 10,57$ & $84,64 \pm 28,99$ & $\begin{array}{c}\text { Penurunan } \\
6,3 \%\end{array}$ \\
\hline P1 & $92,9 \pm 13,10$ & $76,3 \pm 11,07$ & $\begin{array}{c}\text { Penurunan } \\
17,86 \%\end{array}$ \\
\hline P2 & $90,68 \pm 12,17$ & $85,22 \pm 16,77$ & $\begin{array}{c}\text { Penurunan } \\
6,02 \%\end{array}$ \\
\hline P3 & $73,5 \pm 16,74$ & $83,44 \pm 22,93$ & $\begin{array}{c}\text { Penaikan } \\
13,52 \%\end{array}$ \\
\hline
\end{tabular}

Analisis bivariat pengaruh pemberian ekstrak biji melinjo terhadap kadar trigliserida pada tikus dengan diet tinggi lemak menunjukkan tidak adanya perbedaan rata-rata kelompok berpasangan di semua kelompok perlakuan $(p>0,05)$

Tabel 2. Hasil analisis paired sample t-test trigliserida

\begin{tabular}{|c|c|c|c|c|c|}
\hline & & Rerata Kada & Trigliserida & & \\
\hline & $\mathbf{n}$ & $(\mathrm{mg} / \mathrm{c}$ & \pm (SD) & Rerata & $p$ \\
\hline & & Sebelum & Sesudah & & \\
\hline K- & 5 & $89,96 \pm 8,09$ & $80,66 \pm 14,05$ & $9,3 \pm 17,99$ & 0,312 \\
\hline $\mathrm{K}_{+}$ & 5 & $90,36 \pm 10,57$ & $84,64 \pm 28,99$ & $5,72 \pm 30,63$ & 0,698 \\
\hline P1 & 5 & $92,9 \pm 13,10$ & $76,3 \pm 11,07$ & $16,6 \pm 21,53$ & 0,160 \\
\hline P2 & 5 & $90,68 \pm 12,17$ & $85,22 \pm 16,77$ & $5,46 \pm 8,25$ & 0,213 \\
\hline P3 & 5 & $73,5 \pm 16,74$ & $83,44 \pm 22,93$ & $-9,94 \pm 8,81$ & 0,065 \\
\hline
\end{tabular}

\section{PEMBAHASAN}

Subjek yang digunakan adalah sebanyak 30 ekor tikus putih jantan (Rattus novergicus) galur Wistar yang diberi diet tinggi lemak dengan menggunakan otak sapi. Lima ekor tikus tidak dapat bertahan hidup saat aklimatisasi sehingga subjek 
tersisa sebanyak 25 ekor namun jumlah tersebut masih memenuhi syarat minimal sampel hewan coba untuk eksperimen. ${ }^{13}$

Pemberian diet otak sapi ke hewan coba bertujuan untuk meningkatkan kadar lipid pada tikus sehingga dapat terlihat apakah terdapatnya perubahan kadar trigliserida pada tikus. Otak sapi dikukus, disuspensikan dengan aquades dengan perbandingan 1:1 dengan menggunakan blender. Otak sapi diberikan sebanyak $2 \mathrm{ml} /$ hari dengan cara disonde langsung ke tikus. Menurut Pratama dan Probosari, setiap 100 gram otak sapi terdapat sekitar 2 gram kolesterol dan 2,9 gram asam lemak jenuh. ${ }^{14}$

Pemberian otak sapi dilakukan selama 29 hari pada kelompok $\mathrm{K}+, \mathrm{P} 1, \mathrm{P} 2$, dan P3. Hasi pemeriksaan kadar trigliserida setelah dilakukan pemberian otak sapi selama 29 hari pada kelompok kontrol positif tidak menunjukkan adanya kenaikan trigliserida yang cukup besar bila dibandingkan kelompok kontrol negatif. Rerata trigliserida pada kelompok K- yang hanya diberi pakan standard dan air minum ad libitum menunjukkan hasil yang cukup tinggi, namun terlihat adanya penurunan kadar trigliserida yaitu dari $89,96 \mathrm{mg} / \mathrm{dL}$ menjadi 80,66 $\mathrm{mg} / \mathrm{dL}$ sedangkan juga terjadi penurunan rerata kadar trigliserida terjadi pada kelompok $\mathrm{K}+$ yaitu dari 90,36 $\mathrm{mg} / \mathrm{dL}$ menjadi $84,64 \mathrm{mg} / \mathrm{dL}$ atau sebesar $6,3 \%$.

Kadar trigliserida menurun pada kelompok kontrol positif namun lebih kecil penurunannya bila dibandingkan dengan kelompok kontrol negatif. Hasil penelitian ini berlawanan dengan penelitian yang dilakukan oleh Slamet pada 2008 yang mengemukakan bahwa pemberian otak sapi dengan dosis $2 \mathrm{ml} /$ hari selama 14 hari dapat meningkatkan kadar kolesterol LDL dengan rerata kenaikan mencapai $68 \% .^{15}$ Yamada mengemukakan bahwa kadar kolesterol berkorelasi positif dengan kadar trigliserida. ${ }^{16}$ Tidak naiknya kadar trigliserida setelah diberi diet tinggi lemak dimungkinkan karena kurang terkontrolnya pakan standar yang dikonsumsi untuk setiap tikus, penempatan tikus yang terlalu banyak pada satu kandang yaitu lima tikus untuk setiap kandang dan siklus siang malam yang tidak dijalankan ketika penelitian berlangsung.
Pakan standar diketahui juga mengandung kolesterol yang cukup tinggi namun konsentrasi tersebut kemungkinan juga dipengaruhi senyawa sterol lain yang ikut terbaca serapannya. Salah satu komponen penyusun yang diperkirakan ada pada pakan standar tersebut adalah sterol. Konsumsi pakan standar yang berlebihan pada kelompok kontrol negatif memungkinkan tingginya kadar lemak pada hewan coba. $^{17}$ Salah satu prinsip refinement (memperlakukan hewan coba secara manusiawi) yaitu dengan membebaskan hewan coba dari ketidaknyamanan, disediakan lingkungan yang bersih dan paling sesuai dengan biologi hewan percobaan yang dipilih. ${ }^{18}$ Idealnya diperlukan satu kandang untuk satu individu hewan coba untuk menerapkan salah satu prinsip tersebut. ${ }^{19}$ Cahaya merupakan variabel lingkungan yang penting yang berpotensi mempengaruhi kesehatan dan kebiasaan pada tikus, maka dari itu penting untuk mengatur siklus cahaya pada tikus. $^{20}$

Rerata kadar trigliserida pada kelompok P1 pre dan posttest menunjukkan penurunan yang paling besar di antara kelompok perlakuan yaitu dari 92,86 $\mathrm{mg} / \mathrm{dL}$ menjadi $76,3 \mathrm{mg} / \mathrm{dL}$ atau sebesar $17,86 \%$. Penurunan tersebut tidak signifikan menurut analisis dengan uji paired T-test. Kandungan resveratrol melinjo yang terdapat di dalam ekstrak biji melinjo diduga merupakan faktor yang paling berperan di dalam penurunan trigliserida. Mekanisme resveratrol dalam menurunkan trigliserida yang juga dapat menurunkan risiko terkenanya penyakit kardiovaskular melalui oksidasi kolesterol LDL dan modulasi metabolisme lipid, juga sebagai penghambat sintesis eikosanoid dan agregasi platelat. Efek dari resveratrol juga dapat dihasilkan dari fosforilase atau pengaktivan dari 5'-AMP-protein pengaktif kinase (AMPK). AMPK menghambat asetil-KoA karboksilase untuk meningkatkan oksidasi asam lemak dan menekan sintesisnya. $^{21}$ Faktor lain yang menyebabkan penurunan cukup besar pada kelompok ini dimungkinkan karena adanya aktivitas enzim HMG$K o A$ reduktase. Hafidz et al menemukan bahwa terdapat aktivitas enzim tersebut pada ekstrak biji melinjo. $^{22}$ HMG-KoA reduktase difosforilasi, kemudian 
diinaktivasi oleh sebuah enzim AMP kinase, yang juga memfosforilasi dan menginaktivasi asetil-KoA karboksilase, enzim penentu dari biosintesis asam lemak. $^{23}$ Efek tersebut saling mempengaruhi satu sama lain.

Penurunan yang tidak signifikan pada kelompok P1 dan P2 sesuai dengan penelitian yang dilakukan oleh Konno pada 2013. Penelitian tersebut tidak mampu membuktikan efek menguntungkan dari ekstrak biji melinjo pada kolesterol LDL dan trigliserida dengan dosis $750 \mathrm{mg}$ yang diberikan kepada manusia sehat selama 8 minggu. Konno et al mengemukakan bahwa ekstrak biji melinjo mungkin menguntungkan untuk mencegah aterosklerosis tanpa perubahan metabolisme LDL melainkan dengan adanya peningkatan pada HDL. ${ }^{24}$

Rerata kadar trigliserida pada kelompok P3 pre dan posttest menunjukkan kenaikan sebesar $13,52 \%$ yaitu dari $73,5 \mathrm{mg} / \mathrm{dL}$ menjadi $83,44 \mathrm{mg} / \mathrm{dL}$. Efek yang ditimbulkan pada kelompok berlawanan dengan kelompok P1 dan P2. Hal ini dimungkinkan karena adanya kandungan dari ekstrak biji melinjo yang menimbulkan efek berlawanan. Penggunaan obat herbal tidak selamanya menghasilkan efek yang diinginkan. Sama halnya dengan konsumsi obat dengan zat murni yang membutuhkan dosis yang tepat sehingga tidak memliki efek samping. Hal ini berlawanan dengan anggapan bahwa obat tradisional tidak memiliki efek samping sehingga dibutuhkan kajian lebih lanjut mengenai batas aman penggunaan ekstrak biji melinjo pada suatu individu. ${ }^{25}$

\section{SIMPULAN}

Pemberian ekstrak biji melinjo dengan dosis $250 \mathrm{mg} / \mathrm{kg} / \mathrm{hari}, 500 \mathrm{mg} / \mathrm{kg} /$ hari, dan $2000 \mathrm{mg} / \mathrm{kg} / \mathrm{hari}$ tidak dapat menurunkan kadar trigliserida pada tikus dengan diet tinggi lemak.

\section{DAFTAR PUSTAKA}

1. Velayutham P, Babu A, Liu P. Green tea cathechins and cardiovascular health: An update. Curr Med Chem. 2008;15(18):1840-50.

2. Kementerian Kesehatan Republik Indonesia. Pusat Data dan Informasi. Situasi kesehatan jantung. 2014(diunduh Oktober 2017)Tersedia dari: http://www.depkes.go.id/resources/download/pusd atin/infodatin/infodatin-jantung.pdf

3. World Health Organization (WHO). Global status report on noncommunicable diseases. 2014 (diunduh Oktober 2017). Tersedia dari: http://apps.who.int/iris/bitstream/handle/10665/148 114/9789241564854 eng.pdf;jsessionid=FE7CB9 A49F0DDA7D5C11DE2E72A89B49? sequence $=1$

4. Hall JE, Guyton AC. Buku ajar fisiologi kedokteran. Edisi ke-12. Ilyas E (penterjemah). Guyton and Hall Textbook of Medical Physiology. Singapore: Elsevier Singapore Pte Ltd; 2014.hIm.855-98.

5. National Institutes of Health. ATP III guidelines ata-glance quick desk reference. National Institutes of Health Department of Health and Human Services. 2001 (diunduh Oktober 2017). Tersedia dari: https://catalog.nhlbi.nih.gov/sites/default/files/ publicationfiles/01-3305.pdf

6. Jeppesen J, Hein HO, Suadicani P, Gyntelberg F. Triglyceride concentration and ischemic heart disease: an eight-year follow-up in the Copenhage male study. Circulation Journal of American Heart Association. 1998;97:1029-36.

7. Rohmah NJ. Pengaruh pemberian beberapa jenis tepung kacang terhadap penurunan resiko atherosklerosis pada tikus putih (Rattus norvigicus L) akibat diet tinggi (skripsi). Malang : UIN Maulana Malik Ibrahim; 2010.

8. Mufidah. Aktivitas antiaterosklerosis ekstrak terstandar klika ongkea (Mezzetia parviflora becc.) pada tikus wistar yang diberi asupan kolesterol : kajian efek anti-oksidan dan anti-kolesterol terhadap penghambatan MCP-1 dan disfungsi endotel (disertasi). Makassar: Universitas Hasanudin; 2011.

9. Dachriyanus DO, Katrin RO, Oktarina O, Ernas, Suhatri, Mukhtar MH. Uji efek a-mangostin terhadap kadar kolesterol total, trigliserida, kolesterol HDL, dan kolesterol LDL darah mencit putih jantan serta penentuan lethal dosis $50\left(\mathrm{Ld}^{50}\right)$. J. Sains Tek. Far. 2007;12(2): 64-72.

10. Ikuta T, Saito S, Tani H, Tatefuji T, Hashimoto K. Resveratrol derivative-rich melinjo (Gnetum gnemon L.) seed extract improves obesity and survival of C57BL/6 mice fed a high-fat diet. 
Bioscience, Biotechnology, and Biochemistry. 2015; 79(12): 2044-9.

11. Sari RK. Uji efektivitas protein biji melinjo (Gnetum gnemon L.) sebagai inhibitor aktivitas $\alpha$-amilase dan a-glukosidase secara in vitro (skripsi). Jember; Universitas Jember. 2015.

12. Wong RHX, Howe PRC, Buckley JD, Coates AM, Kunz I, Berry NM. Acute resveratrol supplementation improves flow-mediated dilatation in overweight/obese individuals with mildly elevated blood pressure. Nutrition, Metabolism and Cardiovascular Diseases. 2011;21(11):851-6.

13. World Health Organization (WHO). General guideline for methodologies on research and evaluation of traditional medicine. Geneva: WHO; 2000. (diunduh Oktober 2017). Tersedia dari: http://apps.who.int/iris/bitstream/handle/10665/667 83/WHO EDM TRM 2000.1.pdf;jsessionid=96D6 CAF66348A6CD0C778BD75359A3EB? sequence $=$

14. Pratama ES, Probosari E. Pengaruh pemberian kefir susu sapi terhadap kadar kolesterol LDL tikus jantan Sprangue Dawley hiperkolesterolemia. Journal of Nutrition Collage. 2012;1(1):358-64.

15. Slamet S. Pengaruh pemberian yoghurt kedelai hitam (Black soyghurt) terhadap profil lipid tikus hiperkolesterolemia (skripsi). Semarang: Universitas Diponegoro; 2008

16. Yamada N. Control of triglyceride. Asian Med. J. 2001;44(1):42-7.

17. Hardiningsih R, Nurhidayat N. Pengaruh pemberian pakan hiperkolesterolemia terhadap bobot badan tikus putih wistar yang diberi bakteri asam laktat. Biodiversitas. 2006; 7(2):127-30.

18. Ridwan E. Etika pemanfaatan hewan percobaan dalam penelitian kesehatan. J Indon Med Assoc. 2003;63:112-6.
19. Widiartini W, Siswati E, Setiyawati A, Rohmah IM, Prastyo E. Pengembangan usaha produksi tikus putih (Rattus norvegicus) tersertifikasi dalam upaya memenuhi kebutuhan hewan laboratorium. Direktorat Pendidikan Tinggi. (dinduh April 2018). Tersedia dari: http://artikel.dikti.go.id/index.php/ PKMK/article/viewFile/149/150

20. Schlingmann FS, De Rijk HLM, Pereboom WJ, Remie R. Avoidance as a behavioural parameter in the determination of distress among albino and pigmented rats at various light intensities. Animal Technology. 1993; 44(2):87-96.

21. Shahi MM, Haidari F, Shiri MR. Comparison of effect of resveratrol and vanadium on diabetes related dyslipidemia and hyperglycemia in streptozotocin induced diabetic rats. Advanced Pharmaceutical Bulletin. 2011;1(2):81-6

22. Hafidz KA, Puspitasari N, Azminah, Yanuar A, Artha $Y$, Mun'im A. HMG-CoA reductase inhibitory activity of Gnetum gnemon seed extract and identification of potential inhibitors for lowering cholesterol level. J Young Pharm. 2017; 9(4):55965.

23. Goldstein JL, Brown MS. Regulation of the mevalonate pathway. Nature. 1990;343(6257): 425-30.

24. Konno $\mathrm{H}$, Kanai $\mathrm{Y}$, Katagiri M, Watanabe $\mathrm{T}$, Mori $\mathrm{A}$, Ikuta T, et al. Melinjo (Gnetum gnemon L.) seed extract decreases serum uric acid levels in nonobese Japanese males: a randomized controlled study. Evid Based Complement Alternat Med. 2013; (2013):589169.

25. Sari LO. Pemanfaatan obat tradisional dengan pertimbangan manfaat dan keamanannya. Majalah IImu Kefarmasian. 2006;3(1):1-7. 